\title{
ffPS Overseas Tours
}

Two ffPS African tours have been arranged for August and September this year. The first comprises two weeks in Zambia, including six days at Norman Carr's Chibembe Camp, and an optional week in Zimbabwe: August 11-29. The second also spends two weeks in Zambia (Luangwa Valley and Kafue National Park), preceded by an optional week in Botswana on the Okavango Delta: September 3-24. Full details from the ffPS.

\section{Madagascar, Réunion and Mauritius - The leader writes:}

The animals behaved beautifully on the ffPS tour to Madagascar and Mauritius. At Perinet in Madagascar's eastern rain forest, a pair of indri, largest of the island's twenty lemur species, posed for an hour for our whirring cameras. They had a playful two-month baby, and twice the pair lifted their muzzles and sang, while the hills re-echoed with the howls of answering groups. In all the times I have visited Perinet since 1962, I have never watched indri so long, so close, or so amusingly.

In Berenty, a gallery forest reserve in the spiny desert of the far south, where $M$. and Mme Jean de Heaulme opened two houses for us to stay at the reserve itself, ring tailed lemurs promenaded over the red sand, tails raised in a series of striped question-marks. White sifaka soared between the trees, or bounced like furry ping-pong balls on the ground. On idyllic Nosy Bé we relaxed on a coconut palm beach and took a day-trip to the islet of Nosy Komba, where black and golden lemurs jumped on our shoulders to beg bananas.

On Réunion we drove to the active volcano, the Pic de la Fournaise, upward through layers of vegetation, including one where fuchsias and hydrangeas have gone wild to bloom among the native tree-ferns. Our only regret was not to spend longer in montane rainforest and heath, or climb the final forbidding cinder cone.

Finally, Mauritius, where Wahab Owadally, the Chief Conservator of Forests, guided us through the Maccabe area himself, pointing out the cyclone-stripped skeletons of endemic trees and the forest department's beds of carefully nurtured seedlings. Mauritius's chief threat is introduced species; Chinese guava and Japanese privet simply out-compete the slow growing native trees. It is amazing to be in a place where both plants and animals are down to numbered individuals, each following the dodo into extinction. Wahab showed us some of the score of tambalacoque trees, and all four Gaertnera longifolia (blooming for the first time in two years, with a flower head the size of a man's fists). On that first day we saw the endemic cuckoo-shrike, and the Mauritius fody, whose male looks as though it fell head-first into a pot of scarlet paint, but stuck at the shoulders ( 40 pairs left?). Finally, three of the world's population of five echo parakeets wheeled over our heads like flashes of emerald fire. The few who rose at 3.30 one morning to accompany ornithologist Carl Jones and Tony Gardiner of the Forestry Department to the pink pigeon wood, saw two pairs, plumped up like rosy sofa pillows in the sunrise. This was encouraging as the cyclone of Christmas 1979 reduced the world population from 40 to perhaps 10 . 
Falkland Islands -The leader writes:

The particular attraction of the ffPS tour to the Falkland Islands in December was the opportunity to call at a number of the small outlying islands that seldom receive visitors. It is these remote islets that retain the tussock grass formations that are the traditional habitat for many species and which were such a prominent feature of the islands in the early years of their discovery.

Large rookeries of the three penguins - gentoo, magellanic and rockhopper - were seen, together with colonies of black-browed albatross, kelp and dolphin gulls and king cormorants. Each island in its way offered something new or of special interest. Thus, Carcass has a large and vociferous colony of black-crowned night-herons and an abundance of small landbirds - cinclodes, ground-tyrant, Falkland thrush. New Island, regarded as one of the best wildlife areas, is remarkable not only for its penguin rookeries but for prions and fur seals. Large and bellicose sealions seem to congregate on the quaintly named Stick-in-the-Mud Islet. Penn Island has nesting colonies of gulls and giant petrels, Keppel black-necked swans, and a freshwater lake on Bleaker teems with waterfowl; here there were the two grebes, Rolland's and silvery, and ruddy-headed as well as the ubiquitous upland geese. An afternoon at Staats Island in West Falkland produced many spectacular views of guanaco. The existence of these wild llamas in the Falklands dates from the last century, but it was in the 1930s that they were brought by the John Hamilton Estates to Staats, where they flourished. Numbers are estimated at 300-400, making it one of the largest concentrations anywhere.

The first of the summer flowers were over by December, but we saw the orchids, Codonorchis lessonii, Gavilea australis and G. macroptera, as well as the Falkland endemics, Arabis macloviana, Gnaphalium affine, Nassauvia gaudichaudii, Senecio littoralis and $S$. vaginatus. Two further unique species, vanilla daisy Leuceria suaveolens and the dainty, nodding pale maiden of Falkland islanders Sisyrinchium filifolium, were flowering freely, a bright backdrop to penguin rookeries on the steep rocky slope near Port Stephens. At Westpoint both the native boxwood Hebe elliptica and Felton's Flower Calandrina feltonii were in flower - the latter one of the rarest of plants, known at one time only from a plant surviving in the garden on this island.

Inevitably, on returning from the Falkands, one brings enduring memories of the warmth and kindness of island people. Day-long excursions were made at Keppel, Carcass, New, Westpoint and Sealion Islands, and the most gracious of hospitality was received at dinner one evening on Beaver. Accomodation throughout was on board the 70-foot motor vessel Copious, skippered by Mike Tuson and a vessel previously associated with expedition tours in the Arctic. Well-equipped for the intricacies of island navigation, it provided an ideal base. Local guiding was ably undertaken by Julian Fitter, who was also responsible for promoting the tour, and by Tony Chater.

ROGER PERRY

\section{Captive Breeding of Endangered Species}

The Proceedings of the third international conference on Breeding Endangered Species in Captivity, sponsored by ffPS and the San Diego Zoological Society and held in San Diego in November 1979, occupy some 200 pages of the 1980 International Zoo Yearbook, Volume 20 (Zoological Society of London, $£ 12 ; £ 18$ paperback). A full review of the Yearbook will be published in the next issue of Oryx. 


\section{Best Buy in Bird Lists}

A Complete Checklist of the Birds of the World, by Richard Howard and Alick Moore, (OUP, £17.50), and The Complete Birds of the World, by Michael Walters (David \& Charles, $£ 12.50$ ).

The best way to evaluate these new complete lists of the birds of the world is to compare them with their three chief competitors: James F. Clements's Birds of the World: a Check List (Two Continents Publishing Group, New York, 1974), Edward S. Gruson's A Checklist of the Birds of the World (Collins, 1976), and the Reference List of the Birds of the World, by John J. Morony, Walter J. Bock and John Farrand, published by the American Museum of Natural History, New York, in 1975. The only feature that all five have in common is a list of birds by Latin scientific name, and in using them I have found Clements the least reliable taxonomically. Of the rest, all except Morony et al give English names, and some indication of distribution (only by regions in Gruson), all except Clements use the accepted Peters order, and all except Walters give a complete index to genera. The two new books each have one unique feature not found in any of the other five: Howard \& Moore list all subspecies, and Walters gives an indication of habitat. But this feature of Walters does not compensate for his lack of an index to genera - he only indexes families.

I still find Morony et al the most useful for quick reference although it is getting rather out of date. I think Howard and Moore get my vote as the best buy of the five for most purposes for which people need a list of world birds. They have everything except the slight luxury of an indication of habitat.

\section{Reports \& Journals}

The Annual Report of NERC's Institute of Terrestrial Ecology, the research rump of the former Nature Conservancy, is establishing itself as a document to look forward to each year. The 1979 issue costs $£ 5$ and fills 154 pages with extremely interesting material, well illustrated in both colour and black and white and ranging over the whole wildlife scene, from the feeding ecology and social organisation of both wild and feral domestic cats to the regeneration of native pinewoods. Much of the work is financed by the Nature Conservancy Council and other government departments, including a survey of the short-tailed shearwater Puffinus tenuirostris in Victoria, Australia, commissioned by the Government of Victoria. It is to be hoped that the remarkable range of research will not be unduly curtailed by the current financial blizzard.

The Department of the Environment's annual report on the Implementation of the Convention on International Trade in Endangered Species of Wild Flora and Fauna (CITES) in the United Kingdom, for 1978 ( $\$ 4.30)$, includes Hong Kong and other dependent territories, some of them with not entirely credible nil returns. The statistics would have been even more valuable if provided with summary tables.

Twenty Years of Conservation in the Galapagos, report of a seminar, gives a brief history of the Charles Darwin Foundation, the Research Station and the National Park, outlines lessons learned so far and proposes future priorities. One of the lessons is that too little has been done to involve the people in Galapagos in the islands' conservation, and there are plans for a new approach. (Greensted Hall, Ongar, Essex.)

A Directory of Wetlands of International Importance in the Western Palaearctic, compiled by Erik Carp for UNEP and IUCN $\$ 27.50$, covers the whole of Europe, as well as Iceland, western Asia as far east as the Urals, Afghanistan and Iran, and Africa north of the Sahara. There is a useful summary of the ecology and conservation problems of each site, the term 'wetlands' being used to cover marshes, estuaries and lakes.

Correction: The price of Atlantic Salmon: Its Future, edited by A.E.J. Went (Fishing News Books), is $£ 10.50$, not $£ 19.50$, as stated in the December Oryx. 